\title{
Recent advances in the application of probiotic yeasts, particularly Saccharomyces, as an adjuvant therapy in the management of cancer with focus on colorectal cancer
}

\author{
Roshanak Sambrani $^{1,2} \cdot$ Jalal Abdolalizadeh $^{3,4}$ (1) $\cdot$ Leila Kohan $^{5} \cdot$ Behboud Jafari $^{6}$
}

Received: 16 September 2020 / Accepted: 18 December 2020 / Published online: 3 January 2021

(c) The Author(s), under exclusive licence to Springer Nature B.V. part of Springer Nature 2021

\begin{abstract}
Today, the increasing rate of cancer-related mortality, has rendered cancer a major global challenge, and the second leading cause of death worldwide. Conventional approaches in the treatment of cancer mainly include chemotherapy, surgery, immunotherapy, and radiotherapy. However, these approaches still come with certain disadvantages, including drug resistance, and different side effects such as gastrointestinal (GI) irritation (e.g., diarrhea, mucositis). This has encouraged scientists to look for alternative therapeutic methods and adjuvant therapies for a more proper treatment of malignancies. Application of probiotics as an adjuvant therapy in the clinical management of cancer appears to be a promising strategy, with several notable advantages, e.g., increased safety, higher tolerance, and negligible GI side effects. Both in vivo and in vitro analyses have indicated the active role of yeast probiotics in mitigating the rate of cancer cell proliferation, and the induction of apoptosis through regulating the expression of cancer-related genes and cellular pathways. Strain-specific anti-cancer activities of yeast probiotics strongly suggest that their administration along with the current cancer therapies may be an efficient method to reduce the side effects of these approaches. The main purpose of this article is to evaluate the efficacy of yeast probiotics in alleviating the adverse effects associated with cancer therapies.
\end{abstract}

Keywords Adjuvant therapy $\cdot$ Apoptosis $\cdot$ Bioactive components $\cdot$ Cancer therapy $\cdot$ Probiotic $\cdot$ Yeast

\section{Introduction}

The World Health Organization (WHO) defines probiotics as "living microorganisms which confer beneficial health effects to the host when administered in adequate amounts"

Jalal Abdolalizadeh

jabdolalizadeh@gmail.com

1 Department of Genetic, Fars Science and Research Branch, Islamic Azad University, Marvdasht, Iran

2 Department of Genetic, Islamic Azad University, Marvdasht Branch, Marvdasht, Iran

3 Drug Applied Research Center, Tabriz University of Medical Sciences, Tabriz, Iran

4 Paramedical Faculty, Laboratory Sciences Department, Tabriz University of Medical Sciences, Tabriz, Iran

5 Department of Biology, Islamic Azad University, Arsanjan Branch, Arsanjan, Iran

6 Department of Microbiology, Islamic Azad University Ahar Branch, Ahar, Iran
[1]. The currently recognized probiotics are mainly categorized into the lactic acid bacteria and yeast groups. Along with various strains of bacteria [2], a big number of yeast species, including Saccharomyces cerevisiae var. boulardii, Kluyveromyces, Debaryomyces, Candida, Pichia, Hanseniaspora, and Metschnikowia have been shown to possess probiotic properties [3]. The primary salutary effects of yeast probiotics, such as their potential for prevention and treatment of intestinal disorders, along with their immunomodulatory properties, have been reviewed in several studies [4]. Likewise, the anti-cancer properties of yeast probiotics have been extensively investigated by different methods in various studies, including cell-based studies, animal models, and clinical trials. Table 1 summarizes the recent application of probiotics and their strain-specific effects mediated through different mechanisms. In this review, we aim to provide a brief account of the beneficial effects of yeast probiotics, with the emphasis on their anti-cancer properties, particularly in the prevention of Colorectal Cancer (CRC). 
Table 1 List of health benefits of probiotics in the treatment of various diseases

\begin{tabular}{|c|c|c|}
\hline Effect & Probiotic strains & Mechanisms of actions \\
\hline \multirow[t]{4}{*}{ Immunomodulation } & Lactobacillus & $\begin{array}{l}\text { Induce TNF- } \alpha \text { secretion by lipoteichoic acid (LTA) } \\
\text { [5] }\end{array}$ \\
\hline & Bifidobacterium longum & $\begin{array}{l}\text { Modulate TNF- } \alpha \text {, IL- } 6 \text {, IL-10 and IL-12 and TH17 } \\
\text { responses [6] due to its surface exopolysaccharide }\end{array}$ \\
\hline & \multirow[t]{2}{*}{ B. animalislactis $\mathrm{Bb}-12$} & Activated intestinal NF-кB [7] \\
\hline & & IgA secretion $[8]$ \\
\hline $\begin{array}{l}\text { Improving the immune system and cytokine } \\
\text { production in COVID-19 patients }\end{array}$ & Lactobacillus & $\begin{array}{l}\text { As adjuvant nutritional therapies in COVID-19 } \\
\text { patients [9-11] }\end{array}$ \\
\hline \multirow[t]{8}{*}{ Protective effects against physiological stress } & L. acidophilus (strain LAP5 and LF33) & $\begin{array}{l}\text { Bind to the intestinal epithelial cells and blocked } \\
\text { the colonization of Salmonella [12] }\end{array}$ \\
\hline & L. acidophilus A4 & $\begin{array}{l}\text { Antagonize adhesion of the } E \text {. coli adhesion to } \\
\text { epithelial cells by up-regulation of mucin-2, IL-8, } \\
\text { IL-1 } \beta \text { and TNF- } \alpha \text { [13] }\end{array}$ \\
\hline & Bifidobacterium spp. & $\begin{array}{l}\text { Produce acetate and inhibit Shiga toxin-producing } \\
\text { E. coli } \mathrm{O} 157: \mathrm{H} 7[14]\end{array}$ \\
\hline & Lactobacilus and Enterococcus & Produce bacteriocins $[15,16]$ \\
\hline & L. salivarius UCC118 & Protect infected mice with L. monocytogenes [17] \\
\hline & L. acidophilus La-5 1 & $\begin{array}{l}\text { Inhibited autoinducer-2 (AI-2) and decreased the } \\
\text { virulence factors expression of E. coli } \mathrm{O} 157: \mathrm{H} 7 \\
{[18]}\end{array}$ \\
\hline & L. acidophilus GP1B & $\begin{array}{l}\text { Prevented AI-2 activity of Clostridioides difficile } \\
\text { [19] }\end{array}$ \\
\hline & L. reuteri $\mathrm{RC}-14$ & $\begin{array}{l}\text { Production of mediators against Staphylococcus } \\
\text { aureus QS, blocked its virulence, and expression } \\
\text { of toxic shock syndrome toxin-1 [20] }\end{array}$ \\
\hline Suppression of pathogens & L. plantarum & $\begin{array}{l}\text { Reduce hydroxy-cis-12-octadecenoic acid via regu- } \\
\text { lation of TNF receptor } 2 \text { expression and MEK/ } \\
\text { ERK pathway [21] }\end{array}$ \\
\hline $\begin{array}{l}\text { Modulation of gut microbiome and Intestinal Bar- } \\
\text { rier Function }\end{array}$ & L. fermentum and L. plantarum & $\begin{array}{l}\text { In context to Obesity [22, 23], Produce Short Chain } \\
\text { Fatty Acids (SCFAs) and Acetic acid, improve } \\
\text { tight junction proteins, regulating the immune } \\
\text { response, and stimulating host defense peptides } \\
\text { [24] }\end{array}$ \\
\hline \multirow[t]{4}{*}{ Other mechanisms } & Lactobacillus and Bifidobacterium & $\begin{array}{l}\text { Reduction weight gain, decrease the levels of } \\
\text { plasma cholesterol and liver triglycerides [25, 26], } \\
\text { bile acids deconjugation [27], impaired glucose } \\
\text { tolerance [28] }\end{array}$ \\
\hline & L. rhamnosus JB-1 & $\begin{array}{l}\text { Modified the } \gamma \text {-aminobutyric acid (GABA)-A } \\
\text { expression and GABA-B receptors in the brain } \\
\text { related to stress and anxiety-related responses } \\
\text { [29] }\end{array}$ \\
\hline & L. reuteri ATCC PTA 6475 & $\begin{array}{l}\text { Showed an anti-nociceptive effect via transient } \\
\text { receptor potential vanilloid } 1 \text {-dependent manner } \\
\text { [30] }\end{array}$ \\
\hline & L. acidophilus NCFM & $\begin{array}{l}\text { Induced expression of } \mu \text {-opioid and cannabinoid } \\
\text { receptors in the gut epithelial cells and presented } \\
\text { analgesic impact [31] }\end{array}$ \\
\hline
\end{tabular}

\section{General overview of yeast probiotics}

To date, several successful attempts have been made at the isolation and characterization of bacterial probiotics (primarily lactobacillus) from different sources, including traditional dairy products, plants, and human biological samples [2, 32-35]. Regardless of the bacterial source of most probiotics, the therapeutic potential of non-pathogenic yeasts probiotics warrants prospective clinical trials in this field. An important advantage of yeast probiotics is that they are highly resistant against gastrointestinal enzymes, bile salts, $\mathrm{pH}$ variations, organic acids, and variations in temperature. For instance, Saccharomyces 
is a non-bacterial prototype harboring the same beneficial properties as the bacterial probiotics. In comparison with bacterial probiotics, the size of yeast cells is 10 times larger, with an optimal growth $\mathrm{pH}$ and temperature of $4.5-6.5$ and $37{ }^{\circ} \mathrm{C}$, respectively. The majority of yeast strains are able to grow at a $\mathrm{pH}$ equal to 3.0 , however, some species can tolerate an even lower $\mathrm{pH}(<1.5)$.

Compared to bacterial probiotics, yeasts possess intrinsic resistance to antibiotics. Non-genetic transferring of antibiotic-resistance genes between bacteria and yeasts may render these probiotics more effective for patients who use antibiotics. Besides, the modification of the immune response is considered an important mechanism to explain the positive effects of yeast probiotics. The structure of yeast cell wall and the secretory bioactive compounds such as $\beta$-glucan, mannoproteins, chitin, and nucleic acids are responsible for the immunostimulatory effects of these organisms [36]. The majority of reported investigations on yeast probiotics in clinical and animal studies have been carried out on Saccharomyces cerevisiae; however, the probiotic effects of Candida strains, Hanseniaspora opuntia, Hortaea werneckii, Meyerozyma guilliermondii, Debaryomyces strains have also been documented [37-39]. S. cerevisiae and S. boulardii are mostly adopted in probiotic adjuvant therapies to treat antibioticassociated diarrhea and bacterial infections, improve the intestinal mucosa, modulate mucosal immune responses, and induce the expression of a heterologous protein with several therapeutic properties [40-42].

$S$. boulardii is most active in the colon, and it can survive the preceding portion of the GI tract until it reaches the colon [43]. Hence, this yeast probiotic would be suitable for human consumption for the treatment of Inflammatory Bowel Disorders (IBD), and any type of gastroenteritis [42, $44,45]$. The optimal growth temperature for Saccharomyces strains ranges from $22{ }^{\circ} \mathrm{C}$ to $30{ }^{\circ} \mathrm{C}$. However, inside the human body, $S$. boulardii is able to survive at up to $37{ }^{\circ} \mathrm{C}$. Owing to its intrinsic resistance to the gastric acid and intestinal bile, S. boulardii is highly likely to survive the effects of antibiotics and proteolysis in the intestinal tract, ultimately improving intestinal inflammations. In an study led by Sougioultzis et al., human HT-29 colonocytes and THP-1 monocytes were immunologically induced with IL- $1 \beta$, TNF- $\alpha$ or LPS combined with the supernatant of $S$. boulardii. The study reported that $S$. boulardii hindered the production of IL- 8 in HT- 29 cells by inducing IL- $1 \beta$ or TNF- $\alpha$. Moreover, S. boulardii was also able to inhibit the production of IL- 8 , prevent the degradation of IB- $\alpha$, and counteract the upregulation of NF-kB-DNA through binding to NF-kB reporter gene. The anti-inflammatory effects of this yeast were shown to result in deactivation of NF-kB, and down-regulation of IL-8 in intestinal epithelial cells and monocytes. These findings suggest $S$. boulardii as a potential therapeutic candidate to be used either for the treatment of infectious and non-infectious human intestinal diseases [46].

Kluyveromyces lactis is another yeast probiotic with unique features such as resistance to gastrointestinal digestion, $\beta$-galactosidase activity, and a high potential for adhesion, prevention of enteric pathogens, and production of Short Chain Fatty Acids (SCFAs) [42, 47]. Several beneficial effects of $K$. marxianus strain B0399 have also been investigated, which includes adhesion, metabolic activity, and immunomodulation of gut microbiota. Accordingly, the adhesion of $K$. marxianus to the Caco- 2 cells can ameliorate the inflammatory response by inhibiting pro-inflammatory cytokines, and also improve colonic microbiota by increasing the population of bifidobacteria, and the production of SCFAs (acetate and propionate) [48]. In another investigation, $K$. marxianus S-2-05 and $K$. lactis S-3-05 were isolated from traditional cheese and their activity against Salmonella was evaluated in a GI model. Reportedly, these yeasts were able to survive in the GI environment and form a biofilm on polystyrene surfaces, suggesting their potential for adhesion to Caco-2 cells and probiotic properties [49]. An investigation on the anti-inflammatory effects of $K$. marxianus CIDCA 8154 in IBD concluded that pretreatment of cells with $K$. marxianus might decrease the levels of intracellular reactive oxygen species and IL-6. Moreover, cellular oxidative stress was reported to be modulated by the activation of the SKN-1 transcription factor via the DAF-2 pathway in nematode models [50].

Debaryomyces hansenii is another yeast probiotic strain with immunostimulatory effects on goat leukocytes through $\beta$-glucans. D. hansenii CBS 8339 can survive in bile salts and the acidic $\mathrm{pH}$ of the GI tract, and adhere to the intestinal mucosa. The analysis of immunological and antioxidant properties of this strain confirmed the positive effects of $D$. hansenii on the viability of leukocytes in animal models. On the other hand, a yeast-supplemented diet resulted in the upregulation of TLR receptor genes, modulator genes (such as Raf.1, Syk, and Myd88, AP-1), and cytokine levels (IL$1 \beta$ and TNF- $\alpha$ ). These findings demonstrated that the oral administration of $D$. hansenii CBS 8339 stimulated immune response, antioxidant agents, and immune-associated signaling pathways genes in a short time [51]. Moreover, the effects of $D$. hansenii in combination with Qi-Wei-Bai-Zhu powder were investigated on the gut microbiota of mice with antibiotic-associated diarrhea. The microbial content was evaluated by sequencing the $16 \mathrm{~S}$ rRNA gene to demonstrate the species-wise diversity. The results indicated a high frequency of Bacteroidales S24-7 and Bifidobacterium, suppression of Oscillospira and Ruminococcus, and proliferation of Erysipelotrichaceae and Blautia in the murine models of diarrhea [52]. The main functions of gut microbiota including digestion, metabolism, and modulation of immune reactions depend on its diversity [53]. As mentioned 
earlier, treatment of antibiotic-associated diarrhea with $D$. hansenii, as a part of the intragastric flora, improved the operational taxonomic units of intestinal bacteria and recovered the beneficial bacteria, such as Bacteroidaceae [54]. Follow-up analyses confirmed the potential of $D$. hansenii in the maintenance of the normal microbiome ecology, development of lactase-producing bacteria, and inhibition of opportunistic pathogens $[55,56,39]$. The results obtained from animal studies warrant prospective therapeutic clinical applications of yeast probiotics, with an emphasis on management of diarrhea.

\section{The role of yeast probiotics in the management of cancer}

According to the WHO reports, cancer is a global health problem with $\sim 9.6$ million deaths in 2018 [57]. The most prevalent cancers include lung, breast, colorectal, prostate, skin, and stomach cancer. Yeast probiotics may have important effects on the molecular and cellular pathways, that could be useful in the prevention and treatment of cancers [58]. The basic mechanisms of signal transmission and sensitization underlying the negative regulatory effects of yeasts on cancer cells include modification of microbiota, degradation of carcinogenic substances in the intestinal lumen, production of anti-carcinogenic components like SCFAs, and conjugation of SCFAs to linoleic acid. Modulation of immune responses, improvement of intestinal barriers, inhibition of cell proliferation, and induction of apoptosis are other mechanisms through which yeast probiotics regulate the growth of cancer cells [59].

Cancer (CRC) is the second cause of cancer-related mortality with an annual number of 862,000 deaths. Today, there is a rising debate regarding the efficacy of conventional cancer treatment methods. CRC is a multistage malignancy with various risk factors including genetic factors, familial background, age, gender, nutrition, smoking, and limited physical activity. In search of novel therapeutics, the clinical application of safe yeast probiotics is speculated to yield promising results $[60,61]$. Probiotics could provide a non-expensive and non-invasive adjuvant therapy for the treatment of CRC by modulating the genes and signaling pathways involved in the pathogenesis of CRC. In addition, using probiotic yeasts in the treatment of CRC could reduce the side effects of current cancer therapies. The administration of probiotics to CRC patients could enhance the gut flora, produce antimicrobials materials and anti-carcinogenic agents, remove 32-3 carcinogens, provide intestinal permeability, and improve the function of tight junctions and enzyme activity in CRC patients. However, not all of the probiotic strains possess anti-CRC properties. Hence, further studies are required to identify potent probiotics, as probiotic-based therapeutic agents, to prevent and treat CRC [62].

Shamekhi et al. reviewed the promising biotherapeutic effects of yeast probiotics in the prevention and treatment of CRC [63]. In terms of cancer therapy, S. boulardii and $S$. cerevisiae improve enterocyte tight junctions, modulate host cell signaling, inhibit the activity of ERK1/2 and EGFR signaling, and inactivate tyrosine kinase receptors $[64,65]$ (Table 2). The $\beta$-Glucan of $S$. cerevisiae was reported to stimulate the mammalian immune system, suggesting potential therapeutic implications in the treatment of infectious diseases and cancer [66]. The immunomodulatory effects associated with yeast probiotics mostly involve receptors like Dectin-1, Complement Receptor 3 (CR3) and TLR$2 / 6$. In addition, the immune systems can be modulated by triggering immune cells including macrophages, neutrophils, monocytes, Natural Killer Cells (NKCs), Dendritic cells (DCs), and increasing the opsonic and non-opsonic phagocytosis.

An investigation revealed that upon oral administration, animals were not able to digest a specific chain of $\beta$-glucans (backbone $1 \rightarrow 3$ linear $\beta$-glycosidic). As a result, the excessive $\beta$-glucans are transferred to the proximal small intestine, where a small amount of these molecules are captured by macrophages. After internalization and fragmentation of $\beta$-glucans within these cells, macrophages migrate to the bone marrow and endothelial reticular system. Different immune responses are activated when small fragments of $\beta$-glucans released by macrophages are taken up by other immune cells. It has been confirmed that different sizes of $\beta$-glucans and branching patterns have variable immunogenicity. In this regard, to investigate the effect of $\beta$-glucans in clinical studies, a careful selection of probiotics is essential [67]. Further studies have indicated that $\beta$-glucans of yeasts can induce secretion of cytokines, and lead to production of IL-12 in DCs. In one study, the production of cytokines was noticeably reduced in Myeloid Differentiation factor 88 (MyD88)-deficient macrophages and DCs. These findings indicated that $\beta$-glucans could be used in adjuvant therapy of cancer due mostly to their bioavailable moiety, and their modulatory effects on the cytokine secretion through DCs, and phagocytosis of iC3b-opsonised tumor cells by macrophages [68]. Another study conducted on animal cancer models confirmed that a combination of yeast $\beta$-glucans with anti-cancer monoclonal antibodies would improve the clinical therapeutic efficacy in tumor regression and long-term survival during cancer treatment [69]. It has been revealed that $S$. cerevisiae is considerably suppressed in CRC. The beneficial effects of yeasts on Colorectal Adenoma (CRA) were validated by in vivo (C57BL/6 and APCMin/+ mouse models) and in vitro cells assays. Murine models of CRA/CRC were divided into test and control groups, with the former receiving $S$. cerevisiae, 


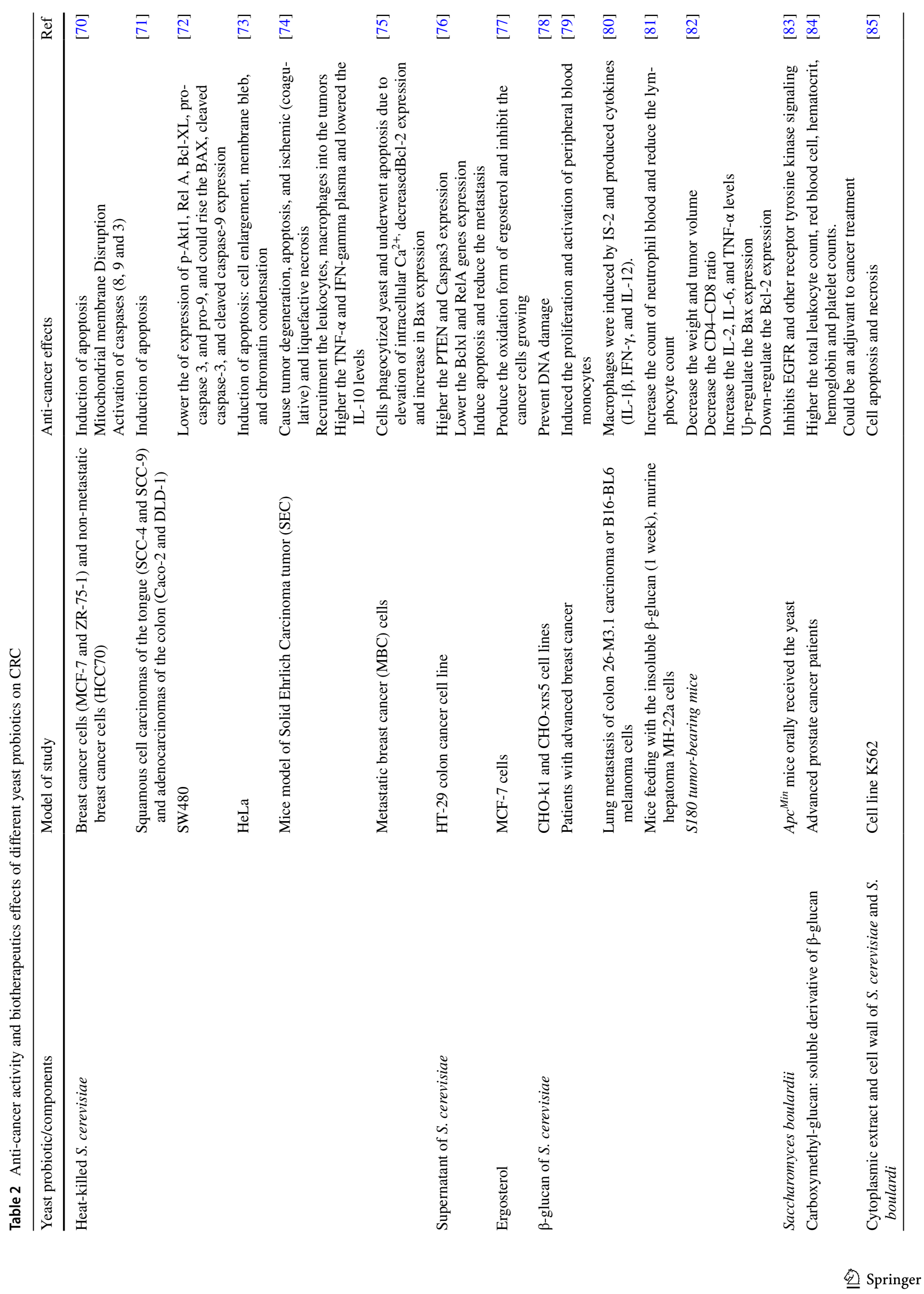




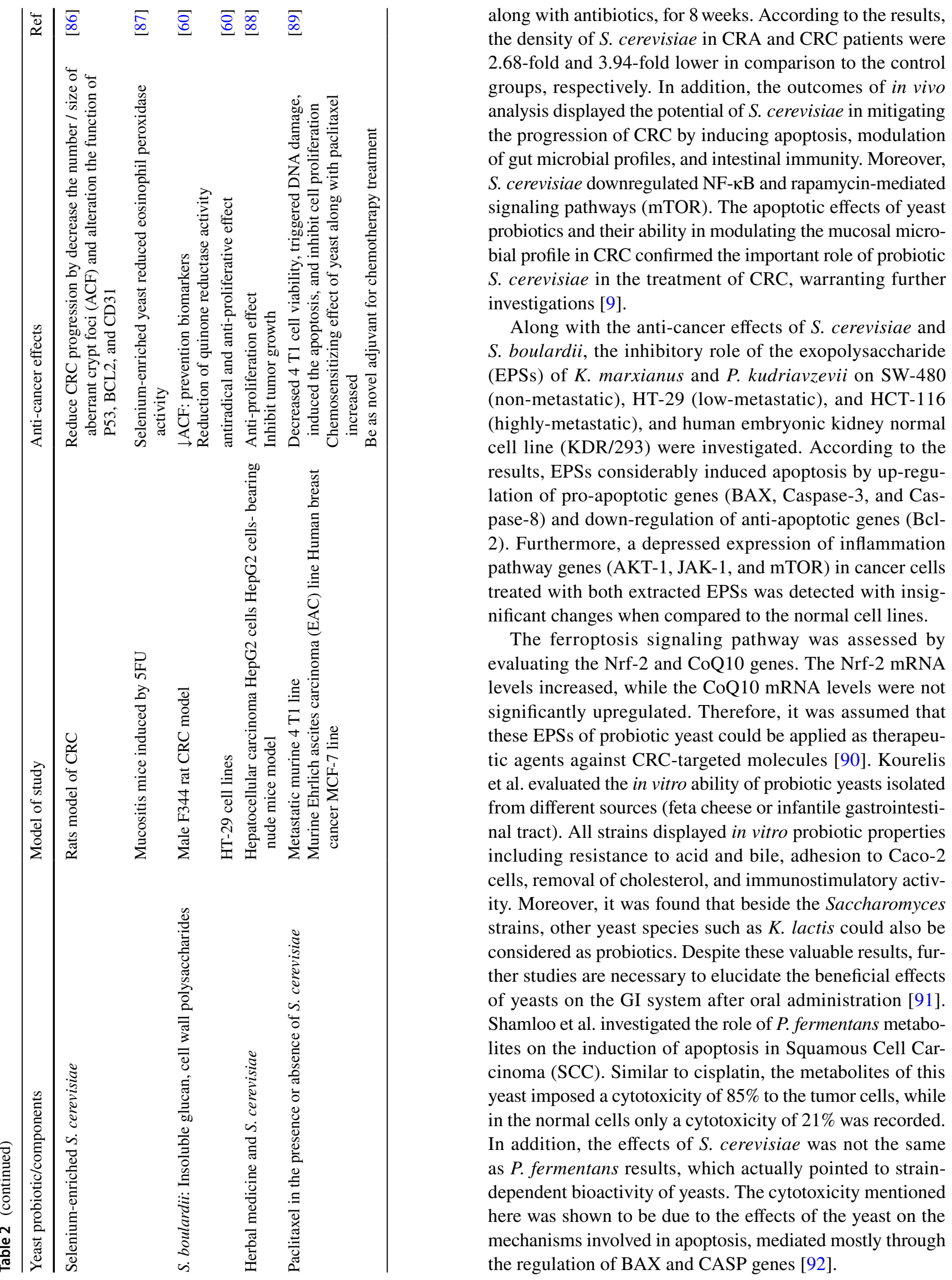




\section{Conclusion}

According to the recent studies, $S$. cerevisiae is a safe microorganism that can be used as a promising therapeutic approach for effective inhibition of tumor cell proliferation. More robust and coherent studies on the effects of probiotics on cancer cell types are required to achieve more reliable results. This can be an important step in the treatment and prevention of cancer. Until now, efficient therapies using yeast probiotics have been confirmed for the treatment of different diseases. However, finding the exact dosage and viability potential of yeast probiotics still remains a significant challenge. This requires further well-designed clinical studies to elucidate the exact benefits of probiotics, identify and demonstrate their criteria and strain-specific properties, and assess their biosafety. Furthermore, increasing the half-life of probiotic products, preservation against the GI secretions, and raising the adherence potential of these microorganisms to the GI epithelium are all essential in this context. Gene technology can help discover novel potential yeast strains. Application of a combination of probiotics may leave a greater positive impact on the efficacy of cancer treatment regimens when compared to a single probiotic. Given the confirmed anti-cancer potentials of probiotics, a wide range of these microorganisms has recently been considered for their immunomodulatory effects and antiviral activity, especially against Coronavirus Disease-2019 (COVID19). However, since COVID-19 is a newly spreading viral infection with a high rate of mortality, more researches are necessary to affirm probiotics as a safe and effective therapy against COVID-19.

Author contributions All authors equally contributed in the wiring of the manuscript.

Funding Funding was provided by Drug Applied Research Center, Tabriz University of Medical Sciences.

\section{Compliance with ethical standards}

Conflict of interest All authors declare that they have no conflict of interest.

\section{References}

1. Vieira AT, Teixeira MM, Martins FS (2013) The role of probiotics and prebiotics in inducing gut immunity. Front Immunol 4:445

2. Nami Y, Vaseghi Bakhshayesh R, Mohammadzadeh Jalaly H, Lotfi H, Eslami S, Hejazi MA (2019) Probiotic properties of enterococcus isolated from artisanal dairy products. Front Microbiol 10:300. https://doi.org/10.3389/fmicb.2019.00300
3. Smith IM, Baker A, Arneborg N, Jespersen L (2015) Non-saccharomyces yeasts protect against epithelial cell barrier disruption induced by Salmonella enterica subsp. enterica serovar Typhimurium. Lett Appl Microbiol 61(5):491-497. https://doi. org/10.1111/lam.12481

4. Moslehi-Jenabian S, Lindegaard L, Jespersen L (2010) Beneficial effects of probiotic and food borne yeasts on human health. Nutrients 2(4):449-473

5. Matsuguchi T, Takagi A, Matsuzaki T, Nagaoka M, Ishikawa K, Yokokura T, Yoshikai Y (2003) Lipoteichoic acids from Lactobacillus strains elicit strong tumor necrosis factor alpha-inducing activities in macrophages through Toll-like receptor 2. Clin Diagn Lab Immunol 10(2):259-266. https://doi.org/10.1128/ cdli.10.2.259-266.2003

6. von Ossowski I, Pietilä TE, Rintahaka J, Nummenmaa E, Mäkinen V-M, Reunanen J, Satokari R, de Vos WM, Palva I, Palva A (2013) Using recombinant Lactococci as an approach to dissect the immunomodulating capacity of surface piliation in probiotic Lactobacillus rhamnosus GG. PLoS One 8(5):e64416

7. Ardita CS, Mercante JW, Kwon YM, Luo L, Crawford ME, Powell DN, Jones RM, Neish AS (2014) Epithelial adhesion mediated by pilin $\mathrm{SpaC}$ is required for Lactobacillus rhamnosus GG-induced cellular responses. Appl Environ Microbiol 80(16):5068-5077

8. Galdeano CM, Perdigon G (2006) The probiotic bacterium Lactobacillus casei induces activation of the gut mucosal immune system through innate immunity. Clin Vaccine Immunol 13(2):219-226

9. Morais AHA, Passos TS, Maciel BLL, da Silva-Maia JK (2020) Can probiotics and diet promote beneficial immune modulation and purine control in coronavirus infection? Nutrients 12(6): 1737

10. Mak JW, Chan FK, Ng SC (2020) Probiotics and COVID-19: one size does not fit all. Lancet Gastroenterol Hepatol 5(7):644-645

11. Conte L, Toraldo DM (2020) Targeting the gut-lung microbiota axis by means of a high-fibre diet and probiotics may have antiinflammatory effects in COVID-19 infection. Ther Adv Respir Dis 14:1753466620937170

12. Tsai CC, Hsih HY, Chiu HH, Lai YY, Liu JH, Yu B, Tsen HY (2005) Antagonistic activity against Salmonella infection in vitro and in vivo for two Lactobacillus strains from swine and poultry. Int J Food Microbiol 102(2):185-194. https://doi.org/10.1016/j. ijfoodmicro.2004.12.014

13. Kim Y, Kim SH, Whang KY, Kim YJ, Oh S (2008) Inhibition of Escherichia coli O157:H7 attachment by interactions between lactic acid bacteria and intestinal epithelial cells. J Microbiol Biotechnol 18(7):1278-1285

14. Fukuda S, Toh H, Hase K, Oshima K, Nakanishi Y, Yoshimura K, Tobe T, Clarke JM, Topping DL, Suzuki T (2011) Bifidobacteria can protect from enteropathogenic infection through production of acetate. Nature 469(7331):543-547

15. Cotter PD, Hill C, Ross RP (2005) Bacteriocins: developing innate immunity for food. Nat Rev Microbiol 3(10):777-788

16. Hassan M, Diep DB, Javadzadeh Y, Dastmalchi S, Nes IF, Sharifi Y, Yari S, Farajnia S, Lotfipour F (2012) Prevalence of bacteriocin activities and bacteriocin-encoding genes in enterococcal clinical isolates in Iran. Can J Microbiol 58(4):359-368. https://doi. org/10.1139/w11-136

17. Corr SC, Li Y, Riedel CU, O'Toole PW, Hill C, Gahan CG (2007) Bacteriocin production as a mechanism for the antiinfective activity of Lactobacillus salivarius UCC118. Proc Natl Acad Sci 104(18):7617-7621

18. Medellin-Peña MJ, Wang H, Johnson R, Anand S, Griffiths MW (2007) Probiotics affect virulence-related gene expression in Escherichia coli O157: H7. Appl Environ Microbiol 73(13):4259-4267 
19. Yun B, Oh S, Griffiths M (2014) Lactobacillus acidophilus modulates the virulence of Clostridium difficile. J Dairy Sci 97(8):4745-4758

20. Li J, Wang W, Xu SX, Magarvey NA, McCormick JK (2011) Lactobacillus reuteri-produced cyclic dipeptides quench agr-mediated expression of toxic shock syndrome toxin-1 in staphylococci. Proc Natl Acad Sci 108(8):3360-3365

21. Miyamoto J, Mizukure T, Park S-B, Kishino S, Kimura I, Hirano K, Bergamo P, Rossi M, Suzuki T, Arita M (2015) A gut microbial metabolite of linoleic acid, 10-hydroxy-cis-12-octadecenoic acid, ameliorates intestinal epithelial barrier impairment partially via GPR40-MEK-ERK pathway. J Biol Chem 290(5):2902-2918

22. Dahiya DK, Puniya AK (2015) Evaluation of survival, free radical scavenging and human enterocyte adherence potential of lactobacilli with anti-obesity and anti-inflammatory CLA isomerproducing attributes. J Food Process Preserv 39(6):2866-2877

23. Yadav H, Lee J-H, Lloyd J, Walter P, Rane SG (2013) Beneficial metabolic effects of a probiotic via butyrate-induced GLP-1 hormone secretion. J Biol Chem 288(35):25088-25097

24. Wang J, Ji H, Wang S, Liu H, Zhang W, Zhang D, Wang Y (2018) Probiotic Lactobacillus plantarum promotes intestinal barrier function by strengthening the epithelium and modulating gut microbiota. Front Microbiol 9:1953. https://doi.org/10.3389/fmicb .2018 .01953

25. Joyce SA, MacSharry J, Casey PG, Kinsella M, Murphy EF, Shanahan F, Hill C, Gahan CG (2014) Regulation of host weight gain and lipid metabolism by bacterial bile acid modification in the gut. Proc Natl Acad Sci 111(20):7421-7426

26. Costabile A, Buttarazzi I, Kolida S, Quercia S, Baldini J, Swann JR, Brigidi P, Gibson GR (2017) An in vivo assessment of the cholesterol-lowering efficacy of Lactobacillus plantarum ECGC 13110402 in normal to mildly hypercholesterolaemic adults. PLoS One 12(12):e0187964

27. Begley M, Hill C, Gahan CG (2006) Bile salt hydrolase activity in probiotics. Appl Environ Microbiol 72(3):1729-1738

28. Sarkar A, Lehto SM, Harty S, Dinan TG, Cryan JF, Burnet PW (2016) Psychobiotics and the manipulation of bacteria-gut-brain signals. Trends Neurosci 39(11):763-781

29. Bravo JA, Forsythe P, Chew MV, Escaravage E, Savignac HM, Dinan TG, Bienenstock J, Cryan JF (2011) Ingestion of Lactobacillus strain regulates emotional behavior and central GABA receptor expression in a mouse via the vagus nerve. Proc Natl Acad Sci 108(38):16050-16055

30. Perez-Burgos A, Wang L, McVey Neufeld KA, Mao YK, Ahmadzai M, Janssen LJ, Stanisz AM, Bienenstock J, Kunze WA (2015) The TRPV1 channel in rodents is a major target for antinociceptive effect of the probiotic Lactobacillus reuteri DSM 17938. J Physiol 593(17):3943-3957

31. Rousseaux C, Thuru X, Gelot A, Barnich N, Neut C, Dubuquoy L, Dubuquoy C, Merour E, Geboes K, Chamaillard M (2007) Lactobacillus acidophilus modulates intestinal pain and induces opioid and cannabinoid receptors. Nat Med 13(1):35-37

32. Ryan KA, Jayaraman T, Daly P, Canchaya C, Curran S, Fang F, Quigley EM, O'Toole PW (2008) Isolation of lactobacilli with probiotic properties from the human stomach. Lett Appl Microbiol 47(4):269-274

33. Duangjitcharoen Y, Kantachote D, Ongsakul M, Poosaran N, Chaiyasut C (2008) Selection of probiotic lactic acid bacteria isolated from fermented plant beverages. Pak J Biol Sci 11(4):652

34. Nozari S, Faridvand Y, Etesami A, Ahmad Khan Beiki M, Miresmaeili Mazrakhondi SA, Abdolalizadeh J (2019) Potential anticancer effects of cell wall protein fractions from Lactobacillus paracasei on human intestinal Caco- 2 cell line. Lett Appl Microbiol 69(3):148-154

35. Nozari S, Mohammadzadeh M, Faridvand Y, Tockmechi A, Movassaghpour A, Abdolalizadeh J (2016) The study of extracellular protein fractions of probiotic candidate bacteria on cancerous cell line. Arch Iran Med 19(11):779-785

36. Ortuño J, Cuesta A, Rodríguez A, Esteban MA, Meseguer J (2002) Oral administration of yeast, Saccharomyces cerevisiae, enhances the cellular innate immune response of gilthead seabream (Sparus aurata L.). Vet Immunol Immunopathol 85(1):41-50. https://doi. org/10.1016/S0165-2427(01)00406-8

37. Tovar D, Zambonino J, Cahu C, Gatesoupe FJ, Vázquez-Juárez R, Lésel R (2002) Effect of live yeast incorporation in compound diet on digestive enzyme activity in sea bass (Dicentrarchus labrax) larvae. Aquaculture 204(1):113-123. https://doi.org/10.1016/ S0044-8486(01)00650-0

38. Vohra A, Syal P, Madan A (2016) Probiotic yeasts in livestock sector. Anim Feed Sci Technol 219:31-47. https://doi.org/10.1016/j. anifeedsci.2016.05.019

39. Wu Y, Tang Y, Xiao N-Q, Wang C-H, Tan Z-J (2020) Bacterial lactase gene characteristics in intestinal contents of antibioticassociated diarrhea mice treated with Debaryomyces hansenii. Med Sci Monit: Int Med J Exp Clin Res 26:e920879-e920871

40. Zhaxi Y, Meng X, Wang W, Wang L, He Z, Zhang X, Pu W (2020) Duan-Nai-An, A yeast probiotic, improves intestinal mucosa integrity and immune function in weaned piglets. Sci Rep 10(1):4556. https://doi.org/10.1038/s41598-020-61279-6

41. van der Aa Kühle A, Skovgaard K, Jespersen L (2005) In vitro screening of probiotic properties of Saccharomyces cerevisiae var. boulardii and food-borne Saccharomyces cerevisiae strains. Int J Food Microbiol 101(1):29-39. https://doi.org/10.1016/j.ijfoo dmicro.2004.10.039

42. Palma ML, Zamith-Miranda D, Martins FS, Bozza FA, Nimrichter L, Montero-Lomeli M, Marques ET, Douradinha B (2015) Probiotic Saccharomyces cerevisiae strains as biotherapeutic tools: is there room for improvement? Appl Microbiol Biotechnol 99(16):6563-6570

43. Kelesidis T, Pothoulakis C (2012) Efficacy and safety of the probiotic Saccharomyces boulardii for the prevention and therapy of gastrointestinal disorders. Ther Adv Gastroenterol 5(2):111-125

44. McFarland LV (2010) Systematic review and meta-analysis of Saccharomyces boulardii in adult patients. World J Gastroenterol 16(18):2202

45. Hatoum R, Labrie S, Fliss I (2012) Antimicrobial and probiotic properties of yeasts: from fundamental to novel applications. Front Microbiol 3:421

46. Sougioultzis S, Simeonidis S, Bhaskar KR, Chen X, Anton PM, Keates S, Pothoulakis C, Kelly CP (2006) Saccharomyces boulardii produces a soluble anti-inflammatory factor that inhibits NF- $\mathrm{KB}$-mediated IL-8 gene expression. Biochem Biophys Res Commun 343(1):69-76

47. Oliveira DR, Lopes ACA, Pereira RA, Cardoso PG, Duarte WF (2019) Selection of potentially probiotic Kluyveromyces lactis for the fermentation of cheese whey-based beverage. Ann Microbiol 69(13):1361-1372. https://doi.org/10.1007/s13213-019-01518-y

48. Maccaferri S, Klinder A, Brigidi P, Cavina P, Costabile A (2012) Potential probiotic Kluyveromyces marxianus B0399 modulates the immune response in Caco-2 cells and peripheral blood mononuclear cells and impacts the human gut microbiota in an in vitro colonic model system. Appl Environ Microbiol 78(4):956-964. https://doi.org/10.1128/aem.06385-11

49. Ceugniez A, Coucheney F, Jacques P, Daube G, Delcenserie V, Drider D (2017) Anti-Salmonella activity and probiotic trends of Kluyveromyces marxianus S-2-05 and Kluyveromyces lactis S-3-05 isolated from a French cheese, Tomme d'Orchies. Res Microbiol 168(6):575-582. https://doi.org/10.1016/j.resmi c.2017.03.004

50. Romanin DE, Llopis S, Genovés S, Martorell P, Ramón VD, Garrote GL, Rumbo M (2016) Probiotic yeast Kluyveromyces marxianus CIDCA 8154 shows anti-inflammatory and 
anti-oxidative stress properties in in vivo models. Benefic Microbes 7(1):83-93. https://doi.org/10.3920/bm2015.0066

51. Angulo M, Reyes-Becerril M, Cepeda-Palacios R, TovarRamírez D, Esteban MÁ, Angulo C (2019) Probiotic effects of marine Debaryomyces hansenii CBS 8339 on innate immune and antioxidant parameters in newborn goats. Appl Microbiol Biotechnol 103(5):2339-2352

52. Xie G, Wu Y, Zheng T, Shen K, Tan Z (2020) Effect of Debaryomyces hansenii combined with Qiweibaizhu powder extract on the gut microbiota of antibiotic-treated mice with diarrhea. 3 Biotech 10(3):1-10

53. Qin Z, Yan L, Er-ha Y, Qiang W, Jin T, Yan Z (2010) Research progress in isolation and identification methods of Bifidobacterium and its application. Anim Husbandry Feed Sci 3:5

54. He L, Long C, Liu Y, Guo Y, Xiao N, Tan Z (2017) Effects of Debaryomyces hansenii treatment on intestinal microorganisms in mice with antibiotics-induced diarrhea. 3 Biotech 7(5):347. https://doi.org/10.1007/s13205-017-0953-9

55. He Y, Tang Y, Peng M, Xie G, Li W, Tan Z (2019) Influence of Debaryomyces hansenii on bacterial lactase gene diversity in intestinal mucosa of mice with antibiotic-associated diarrhea. PLoS One 14(12):e0225802

56. Zeng A, Peng M, Liu H, Guo Z, Xu J, Wang S, He L, Tan Z (2019) Effects of Debaryomyces hansenii treatment on intestinal mucosa microecology in mice with antibiotic-associated diarrhea. PLoS One 14(11):e0224730

57. Bray F, Ferlay J, Soerjomataram I, Siegel RL, Torre LA, Jemal A (2018) Global cancer statistics 2018: GLOBOCAN estimates of incidence and mortality worldwide for 36 cancers in 185 countries. CA Cancer J Clin 68(6):394-424

58. Fernández M, Hudson JA, Korpela R, de los Reyes-Gavilán CG (2015) Impact on human health of microorganisms present in fermented dairy products: an overview. BioMed Res Int 2015:412714. https://doi.org/10.1155/2015/412714

59. dos Reis SA, da Conceição LL, Siqueira NP, Rosa DD, da Silva LL, Peluzio MCG (2017) Review of the mechanisms of probiotic actions in the prevention of colorectal cancer. Nutr Res 37:1-19. https://doi.org/10.1016/j.nutres.2016.11.009

60. Fortin O, Aguilar-Uscanga B, Vu KD, Salmieri S, Lacroix M (2018) Cancer chemopreventive, antiproliferative, and superoxide anion scavenging properties of Kluyveromyces marxianus and Saccharomyces cerevisiae var. boulardii cell wall components. Nutr Cancer 70(1):83-96

61. Newton PT (2019) New insights into niclosamide action: autophagy activation in colorectal cancer. Biochem $\mathrm{J}$ 476(5):779-781

62. Sivamaruthi BS, Kesika P, Chaiyasut C (2020) The role of probiotics in colorectal cancer management. Evid-Based Complement Alternat Med 2020:3535982

63. Shamekhi S, Lotfi H, Abdolalizadeh J, Bonabi E, Zarghami N (2020) An overview of yeast probiotics as cancer biotherapeutics: possible clinical application in colorectal cancer. Clin Transl Oncol:1-13

64. Chen X, Yang G, Song J-H, Xu H, Li D, Goldsmith J, Zeng H, Parsons-Wingerter PA, Reinecker H-C, Kelly CP (2013) Probiotic yeast inhibits VEGFR signaling and angiogenesis in intestinal inflammation. PLoS One 8(5):e64227

65. Mirone G, Shukla A, Marfe G (2016) Signaling mechanisms of resistance to EGFR-and anti-angiogenic inhibitors cancer. Crit Rev Oncol Hematol 97:85-95

66. Vetvicka V (2011) Glucan-immunostimulant, adjuvant, potential drug. World J Clin Oncol 2(2):115

67. Chan GC-F, Chan WK, Sze DM-Y (2009) The effects of $\beta$-glucan on human immune and cancer cells. J Hematol Oncol 2(1):25. https://doi.org/10.1186/1756-8722-2-25
68. Driscoll M, Hansen R, Ding C, Cramer DE, Yan J (2009) Therapeutic potential of various beta-glucan sources in conjunction with anti-tumor monoclonal antibody in cancer therapy. Cancer Biol Ther 8(3):218-225. https://doi.org/10.4161/cbt.8.3.7337

69. Yan J, Allendorf DJ, Brandley B (2005) Yeast whole glucan particle (WGP) beta-glucan in conjunction with antitumour monoclonal antibodies to treat cancer. Expert Opin Biol Ther 5(5):691702. https://doi.org/10.1517/14712598.5.5.691

70. Ghoneum M, Gollapudi S (2004) Induction of apoptosis in breast cancer cells by Saccharomyces cerevisiae, the baker's yeast, in vitro. Anticancer Res 24(3a):1455-1463

71. Ghoneum M, Hamilton J, Brown J, Gollapudi S (2005) Human squamous cell carcinoma of the tongue and colon undergoes apoptosis upon phagocytosis of Saccharomyces cerevisiae, the baker's yeast, in vitro. Anticancer Res 25(2A):981-989

72. Shamekhi S, Abdolalizadeh J, Ostadrahimi A, Mohammadi SA, Barzegari A, Lotfi H, Bonabi E, Zarghami N (2020) Apoptotic Effect of Saccharomyces cerevisiae on human colon cancer SW480 cells by regulation of Akt/NF- $\mathrm{KB}$ signaling pathway. Probiotics Antimicrob Proteins 12(1):311-319

73. Rajan T, Benluvankar V, Vincent S (2017) Saccharomyces cerevisiae-induced apoptosis of monolayer cervical cancer cells. Asian J Pharm Clin Res 10(8):63-66

74. Ghoneum M, Badr El-Din NK, Noaman E, Tolentino L (2008) Saccharomyces cerevisiae, the Baker's Yeast, suppresses the growth of Ehrlich carcinoma-bearing mice. Cancer Immunol Immunother 57(4):581-592. https://doi.org/10.1007/s0026 2-007-0398-9

75. Ghoneum M, Matsuura M, Braga M, Gollapudi S (2008) S. cerevisiae induces apoptosis in human metastatic breast cancer cells by altering intracellular $\mathrm{Ca}^{2+}$ and the ratio of $\mathrm{Bax}$ and $\mathrm{Bcl}-2$. Int J Oncol 33(3):533-539

76. Sambrani R, Abdolalizadeh J, Kohan L, Jafari B (2019) Saccharomyces cerevisiae inhibits growth and metastasis and stimulates apoptosis in HT-29 colorectal cancer cell line. Comp Clin Pathol 28(4):985-995

77. Subbiah MT, Abplanalp W (2003) Ergosterol (major sterol of baker's and brewer's yeast extracts) inhibits the growth of human breast cancer cells in vitro and the potential role of its oxidation products. International journal for vitamin and nutrition research Internationale Zeitschrift fur Vitamin- und Ernahrungsforschung Journal International de Vitaminologie et de. Nutrition 73(1):1923. https://doi.org/10.1024/0300-9831.73.1.19

78. Oliveira RJ, Matuo R, da Silva AF, Matiazi HJ, Mantovani MS, Ribeiro LR (2007) Protective effect of $\beta$-glucan extracted from Saccharomyces cerevisiae, against DNA damage and cytotoxicity in wild-type (k1) and repair-deficient (xrs5) CHO cells. Toxicol In Vitro 21(1):41-52. https://doi.org/10.1016/j.tiv.2006.07.018

79. Demir G, Klein HO, Mandel-Molinas N, Tuzuner N (2007) Beta glucan induces proliferation and activation of monocytes in peripheral blood of patients with advanced breast cancer. Int Immunopharmacol 7(1):113-116. https://doi.org/10.1016/j.intim p.2006.08.011

80. Yoon TJ, Kim TJ, Lee H, Shin KS, Yun YP, Moon WK, Kim DW, Lee KH (2008) Anti-tumor metastatic activity of $\beta$-glucan purified from mutated Saccharomyces cerevisiae. Int Immunopharmacol 8(1):36-42. https://doi.org/10.1016/j.intimp.2007.10.005

81. Javmen A, Nemeikaite-Ceniene A, Grigiskis S, Jonauskiene I, Rudenkov M, Kacianauskas D, Mauricas M (2015) S. cerevisiae \$1beta \$-glucan reduced viability of mouse hepatoma cells in vitro. Turk J Biol 39(4):562-566

82. Mo L, Chen Y, Li W, Guo S, Wang X, An H, Zhan Y (2017) Antitumor effects of $(1 \rightarrow 3)$ - $\beta$-d-glucan from Saccharomyces cerevisiae in S180 tumor-bearing mice. Int J Biol Macromol 95:385-392

83. Chen X, Fruehauf J, Goldsmith JD, Xu H, Katchar KK, Koon HW, Zhao D, Kokkotou EG, Pothoulakis C, Kelly CP (2009) 
Saccharomyces boulardii Inhibits EGF receptor signaling and intestinal tumor growth in Apcmin mice. Gastroenterology 137(3):914-923. https://doi.org/10.1053/j.gastro.2009.05.050

84. Magnani M, Castro-Gomez RH, Nobrega Aoki M, Pereira Gregório E, Libos F, Ehara Watanabe MA (2010) Effects of carboxymethyl-glucan from Saccharomyces cerevisiae on the peripheral blood cells of patients with advanced prostate cancer. Exp Ther Med 1(5):859-862

85. Salar M, Amir T, Majid N (2014) Comparison of anti-tumor properties of the cell walls of Saccharomyces cerevisiae and Saccharomyces boulardi probiotics, individually and in combination with iron nanoparticles on K562 cancer cell line. Basic Clin Cancer Res 6(4):37-47

86. Abedi J, Saatloo MV, Nejati V, Hobbenaghi R, Tukmechi A, Nami Y, Khosroushahi AY (2018) Selenium-enriched Saccharomyces cerevisiae reduces the progression of colorectal cancer. Biol Trace Elem Res 185(2):424-432

87. Porto BAA, Monteiro CF, Souza ÉLS, Leocádio PCL, AlvarezLeite JI, Generoso SV, Cardoso VN, Almeida-Leite CM, Santos DA, Santos JRA, Nicoli JR, Pessione E, Martins FS (2019) Treatment with selenium-enriched Saccharomyces cerevisiae UFMG A-905 partially ameliorates mucositis induced by 5-fluorouracil in mice. Cancer Chemother Pharmacol 84(1):117-126. https://doi. org/10.1007/s00280-019-03865-8

88. Chan J, Cheung J, Luk S, Wu Y, Pang S, Fung K (2004) Anticancer and pro-apoptotic effects of an herbal medicine and
Saccharomyces cerevisiae product (CKBM) on human hepatocellular carcinoma HepG2 cells in vitro and in vivo. Immunopharmacol Immunotoxicol 26(4):597-609

89. Badr El-Din NK, Mahmoud AZ, Hassan TA, Ghoneum M (2018) Baker's yeast sensitizes metastatic breast cancer cells to paclitaxel in vitro. Integr Cancer Ther 17(2):542-550

90. Saadat YR, Khosroushahi AY, Movassaghpour AA, Talebi M, Gargari BP (2020) Modulatory role of exopolysaccharides of Kluyveromyces marxianus and Pichia kudriavzevii as probiotic yeasts from dairy products in human colon cancer cells. J Funct Foods 64:103675

91. Kourelis A, Kotzamanidis C, Litopoulou-Tzanetaki E, Scouras ZG, Tzanetakis N, Yiangou M (2010) Preliminary probiotic selection of dairy and human yeast strains. J Biol Res 13:93

92. Shamloo HB, Shahabi A, Aghazadeh Z, Yari Khosroushahi A (2020) Pichia fermentans originates apoptosis in human oral squamous cell carcinoma by over-expressing BAX and CASP 9 genes. Cytotechnology:1-10

Publisher's Note Springer Nature remains neutral with regard to jurisdictional claims in published maps and institutional affiliations. 